\title{
VOLÁNÍ PO ZDANĚNÍ BOHATÝCH
}

\section{Marek Loužek, Hana Lipovská*}

\section{Thomas Piketty: Kapitál v 21. století}

Praha: Euromedia Group, 2015. 664 stran. ISBN 978-80-242-4870-7.

Kniha francouzského ekonoma Thomase Pikettyho Kapitál v 21. století (Capital in the Twenty-First Century, 2013) vyvolává už delší dobu vášnivé diskuse mezi odbornou i laickou veřejností po celém světě. Stala se bestsellerem v New York Times. České vydání knihy lze proto jednoznačně přivítat.

Kniha je rozdělena do čtyř částí a šestnácti kapitol. První část knihy rozebírá důchod a kapitál. Druhá část zkoumá dynamiku poměru mezi kapitálem a důchodem. Třetí část se zabývá strukturou nerovnosti. Čtvrtá část diskutuje regulaci kapitálu v 21. století.

Pikettyho Kapitál lze ovšem jen stěží považovat za akademickou studii, jakkoli se za ni úspěšně vydává. Jádro objemné, téměř sedmisetstránkové knihy tvoří pưvodní článek Capital is Back: Wealth-Income Ratios in Rich Countries, 1700-2010, který pařížský ekonom publikoval společně se svým studentem Gabrielem Zucmanem (Quarterly Journal of Economics, 2014, vol. 129, no. 3, 1155-1210 pp.). Odhlédneme-li od tohoto odborného jádra publikace, sestává Kapitál z mozaiky velmi krátkých kapitol, jejichž názvy příznačně slibují více, než co ve skutečnosti obsahují. Akademického čtenáře nepř́ijemně překvapí absence seznamů literárních zdrojů. Zájemci o technický aparát jsou pak odkázáni na rozsáhlý (téměř stostránkový), značně nepřehledný apendix, který je k dispozici na osobních webových stránkách autora.

Většina závěrů je vztahována $\mathrm{k}$ francouzskému hospodářství, čemuž odpovídá i citace především francouzských zdrojů a ukotvení do francouzské politicko-ekonomické tradice (Piketty se tak např́klad odkazuje na fyziokraty v čele s Françoisem Quesnayem). Kromě národnosti autora však lze tuto frankofonní orientaci vysvětlit i datovými zdroji. Piketty uvádí, že pro Francii jsou díky historickým pramenům k dispozici dlouhé datové řady sahající do 18. století (str. 378-379). Právě data však patří k další slabině knihy. Autor se totiž velmi často odkazuje na databázi Anguse Maddisona. Jakkoli Maddisonovy historické statistiky patří k jednoznačně nejuznávanějším zdrojům, jen stěží je lze považovat za „tvrdác“ data srovnatelná se soudobými ekonomickými statistikami.

Popularizační akcent knihy je dále posilován četnými citacemi dlouhých pasáží z klasické literatury: Jane Austenové, Honoré de Balzaca a Fjodora Michaljoviče Dostojevského. Jakkoli se jedná o zajímavé odbočky, často se snaží působit spíše na čtenářské emoce než na racionální ekonomické myšlení.

Marek Loužek (marek.louzek@vse.cz), Vysoká škola ekonomická v Praze, Národohospodářská fakulta; Hana Lipovská (lipovska.hana@seznam.cz), Masarykova univerzita, Ekonomicko-správní fakulta. 
Základním poselstvím Pikettyho knihy je, že dynamický vývoj tržní ekonomiky a soukromého vlastnictví bez jakýchkoli zásahů spouští významné konvergenční síly související především s šírením znalostí a zvyšováním kvalifikací, ale rovněž spouští divergenční síly, které jsou potenciální hrozbou pro demokratické společnosti a hodnoty sociální spravedlnosti, z nichž vycházejí.

Základní destabilizační silou je možnost, že soukromý výnos kapitálu $r$ může být trvale vyšší než míry růstu důchodu a výroby $g$. Tato základní nerovnost vychází z toho, že $r$ označuje míru kapitálových výnosů (tj. co průměrně vynáší kapitál v průběhu roku ve formě zisku, dividend, úroků, nájmů a dalších kapitálových př́ijmů) a $g$ označuje míru růstu (tj. roční zvýšení důchodu a výroby).

Tato nerovnice představuje podle Pikettyho spíše historický fakt než absolutní logickou nutnost. Míra růstu byla v dějinách lidstva většinou téměř nulová. Vezmeme-li v úvahu demografický i hospodářský růst, globální míra růstu dř́ve trvale nepřekročila $0,1 \%$ či 0,2 \% ročně. Výnos kapitálu byl vždy mnohem vyšší. Jeho průměrná hodnota se pohybuje dlouhodobě kolem 4-5\% za rok.

S průměrným výnosem kapitálu ve výši řádově $4-5 \%$ je podle Pikettyho vysoce pravděpodobné, že nerovnost $r>g$ bude dál platit i v 21. století, jak tomu bylo po celé 19. století až do začátku první světové války. Ve 20. století skoncovaly s minulostí dvě světové války, které citelně snížily výnos z kapitálu a daly vzniknout iluzi, že došlo ke strukturálnímu překonání kapitalismu a jeho zásadního rozporu.

Pikettyho „druhý zákon kapitalismu“ přitom není ničím jiným než (značně zjednodušenou) modifikací Solowova růstového modelu a jeho aplikací důvěrně známých každému studentovi makroekonomie. Samotný Solowův model však Pikettym nastíněné kontroverze ani zdaleka nenaznačuje.

Pokud míra kapitálových výnosů zásadně převyšuje míru růstu (a jak Piketty ukazuje, tak tomu v dějinách téměř vždy bylo), znamená to, že majetky nahromaděné v minulosti se rekapitalizují rychleji než tempo, jímž narůstá výroba a př́ijmy. Proces akumulace a rozdělování majetku obsahuje síly působící směrem $\mathrm{k}$ divergenci, či alespoň k extrémně vysoké úrovni nerovnosti.

Jakmile je míra výnosu kapitálu výrazně vyšší než míra růstu ekonomiky, je dle Kapitálu téměř nevyhnutelné, že dědictví, tj. majetek z minulosti, převládne nad úsporami, tj. majetkem vytvořeným v současnosti. Nerovnost $r>g$ znamená, že minulost má tendenci pohlcovat budoucnost: bohatství vycházející z minulosti narůstá automaticky bez práce a rychleji než bohatství produkované prací, z něhož je možné spořit.

Ve všech společnostech existují dva základní způsoby, jak si zajistit blahobyt: prací či dědictvím. Bez ohledu na to, že majetek padesátníků či šedesátníků pochází z dědictví či aktivního života, za určitou hranicí má kapitál tendenci reprodukovat se sám o sobě a neomezeně se akumulovat. Logika $r>g$ znamená, že podnikatel má vždy tendenci se nakonec proměnit $\mathrm{v}$ rentiéra.

Koncentrace majetku je neúprosná. Piketty cituje statistiky časopisu Forbes (další z Pikettyho zjevně velmi „,v̌deckých“ zdrojů), podle kterých existovalo v roce 1987 sotva 140 dolarových miliardářů, zatímco $\mathrm{v}$ roce 2013 jich bylo už více než 1400 , 
tj. desetkrát více. Jejich majetek se rozrůstal ještě rychleji, z necelých 300 miliard dolarů v roce 1987 na 5400 miliard v roce 2013, což je téměř dvacetinásobné zvýšení. Jakmile je majetek jednou vytvořen, jeho dynamika se začíná ř́dit svou vlastní logikou.

Světová populace dosahovala $\mathrm{v}$ roce 2012 přibližně 7 miliard obyvatel a světový HDP mírně přesahoval 70 bilionů eur, což znamená téměř přesně 10000 eur coby HDP na obyvatele. Pokud odečteme $10 \%$ na amortizaci kapitálu a vydělíme toto číslo dvanácti, dojdeme k průměrnému měsíčnímu př́ímu na obyvatele ve výši 760 eur. Jinými slovy, pokud by světová produkce a př́ijmy byly rozděleny rovně, každý obyvatel planety by pobíral měsíčně př́ijem 760 eur. Ve skutečnosti je většina lidí výrazně chudší.

Podle Simona Kuznetse, kterého Piketty naprííc knihou podrobuje důrazné kritice, bude nerovnost $\mathrm{v}$ průběhu industrializace a hospodářského rozvoje všude opisovat křivku ve tvaru obráceného $U$, tj. nejprve poroste a poté bude klesat. Kuznets tvrdí, že po fázi prirozeného růstu nerovnosti, provázejícího počátek industrializace, tj. zhruba 19. století v USA, následuje fáze výrazného snížení nerovnosti, která se v USA začala projevovat v první polovině 20. století.

Kuznets zjistil, že v USA došlo v letech 1910-1950 k citelnému snížení př́imové nerovnosti. Konkrétně v letech 1910-1920 pobíral nejvyšší decil, tj. 10\% nejbohatších Američanů, každoročně $45-50 \%$ národního důchodu. Na konci 40 . let se podíl připadající na tento decil snížil na 30-35\% národního důchodu. Více než desetibodové snížení je významné, odpovídá polovině toho, co dostává $50 \%$ nejchudších Američanů.

Kuznets se domníval, že ke stejným výsledkům by mohla vést samotná vnitřní logika hospodářského rozvoje, a to nezávisle na jakékoli politické intervenci a vnějších otřesech. Silný růst, který nastal po válce ve všech rozvinutých zemích, je zásadním faktem, a to, že z něj měly prospěch všechny společenské skupiny. Snížení nerovnosti během první poloviny 20 . století je evidentní a nepopiratelné.

Ještě v letech 1950-1970 se nerovnost stabilizovala na této úrovni. Na druhé straně však Piketty upozorňuje, že v letech 1970-1980 došlo k velmi rychlému pohybu opačným směrem, takže podíl nejvyššího decilu se v letech 2000-2010 znovu dostává na úroveň 45-50\% národního důchodu. Rozsah náhlého obratu je ohromující. Je zcela přirozené se ptát, kam až může takový vývoj jít.

Harmonizační sílu, byt' může být velmi silná především v případě sbližování úrovně jednotlivých zemí, může v některých momentech vyvažovat či převážit síla opačná, tj. divergenční, která působí směrem ke zvětšování a násobení nerovnosti. Piketty se zaměřuje na divergenční síly, které jsou o to znepokojivější, že mohou nastat ve světě, kde se investuje do zvyšování odbornosti, nebo kde byly na první pohled splněny všechny podmínky pro to, aby tržní ekonomika účinně fungovala.

V kapitalismu dochází k vyplácení vysokých mezd (především manažerům - Piketty je označuje termínem supermzdy), jednak jde o soubor divergenčních sil souvisejících s procesem akumulace a koncentrace majetku ve společnosti, pro niž je příznačný nízký růst a vysoký kapitálový výnos. Př́ijmová nerovnost ve všech společnostech je vždy součtem těchto dvou složek: jednak nerovnosti pracovních, jednak nerovnosti kapitálových důchodů. 
Nerovnost pracovních důchodů je vždy mnohem nižší než nerovnost ve vlastnictví kapitálu. Piketty však varuje, že by bylo chybou ji opomíjet: jednak proto, že pracovní důchody obvykle představují dvě třetiny až tři čtvrtiny národního důchodu, a jednak proto, že v různých zemích existují dost podstatné rozdíly v rozdělení pracovních důchodů, což svědčí o tom, že na nerovnost a životní podmínky rozsáhlých skupin obyvatel mají zásadní vliv uplatňované politiky a národní specifika.

Společnostem s vyšší koncentrací důchodů (kdy by si horní decil přivlastňoval např. 90 \% zdrojů) by zřejmě učinila př́itrž lidová revoluce, pokud by nefungoval výjimečně účinný represivní aparát. $\mathrm{V}$ př́ípadě vlastnictví kapitálu už i taková míra koncentrace vytváří silné politické tlaky a často se špatně snáší s všeobecným volebním právem. Proto demokratické země vyvinuly nástroje, jak se s nerovností vyrovnat.

Piketty doporučuje zatížit výnos z kapitálu výraznou daňovou sazbou, abychom snížili soukromý výnos pod úroveň míry růstu. Nicméně přiznává, že pokud to uděláme př́liš masivně a bez rozdílů, riskujeme, že zahubíme hnací sílu akumulace a ještě více snížíme míru růstu. Podnikatelé nebudou mít čas proměnit se v rentiéry, protože už žádní nebudou. Přesto Piketty doporučuje zavedení roční progresivní daně z kapitálu.

Současně doporučuje progresivní zdanění příjmů. Horní sazby daně z prŕijmů ve Francii a Německu zůstaly v období 1930-2010 poměrně stabilní (okolo $50 \%$ a 60 \%), americké a britské sazby se z 80\% a 90\% v letech 1930-1980 snížily na 30-40\% v období let 1980-2010. Užívání konfiskační daně na vrcholku příjmové hierarchie je podle Pikettyho nejen možné, ale i legitimní, protože jde o jediný zpo̊sob, jak udržet excesy na nejvyšší úrovni ř́zení podniků.

Evropský vysoký státní dluh lze dle Pikettyho snížit třemi způsoby: zavedením daně z kapitálu, inflací a cestou škrtů, kterou považuje za nejhorší řešení z hlediska spravedlnosti. Vychází přitom z předpokladu, že hodnota tzv. veřejných aktiv (tedy např́iklad budov, škol a nemocnic) přibližně odpovídá výši státního dluhu a že státní dluhy v Evropě vlastní v konečném důsledku především evropské domácnosti. Pokud by tedy státy přistoupily k privatizaci, aby odprodejem veřejných aktiv vyrovnaly státní dluhy, došlo by jen k transmisi aktiv domácností. Ty by nyní nevlastnily státní dluh, nýbrž př́mo veřejná aktiva, která by si od nich státy zpětně pronajímaly.

V souladu s tradicí francouzské hospodářské politiky považuje Piketty za nejuspokojivější řešení vysokých státních dluhů zavedení mimořádné daně ze soukromého kapitálu. Již $15 \%$ daň by podle něj vedla k okamžitému splacení dluhu. Výhodou této výjimečné daně z kapitálu je v jeho optice spravedlnost, nebot' by se tak na splácení dluhu podíleli všichni občané. Piketty přitom nechce ekonomiky oddlužit - na otázku ,jak vysoký dluh je správný“ odpovídá zcela nepochopitelně, že nevíme. V kontrastu k známým ekonomickým teoriím tak zjevně nepovažuje za optimální situaci nulové dluhové břemeno. Místo toho navrhuje nastavit progresivní kapitálovou daň v takové výši, aby došlo ke snížení dluhu o $20 \%$ HDP. Tím by se podle něj průměrný evropský dluh ve výši $90 \%$ HDP přiblížil požadavku fiskálního maastrichtského (konvergenčního) kritéria.

Aby takto definovaná daň z kapitálu mohla fungovat, aniž by docházelo $\mathrm{k}$ odlivu kapitálu do ostatních zemí, chce Piketty zavést finanční katastr. Tento registr by měl 
umožnit úřadům neustálý přístup ke všem mezinárodním informacím o všech aktivech všech občanů. Kromě zmíněných regulatorních opatření vyzdvihuje Kapitál i myšlenku nadnárodní daně z bohatství placené mezinárodním společenstvím (str. 635). V souladu se svými intervencionistickými stanovisky kritizuje Piketty evropskou daňovou konkurenci. Všechny tyto požadavky jsou jen logickým důsledkem Pikettyho internacionalismu a moderního socialismu.

Představa celosvětové daně z kapitálu je zřejmě utopií, ale na úrovni regionální či kontinentální by se podle Pikettyho dala úspěšně aplikovat především v Evropě. Daň z kapitálu by umožnila, aby veřejný zájem převládl nad soukromým a zároveň zůstala zachována otevřenost ekonomiky a konkurenční síly.

Opět v ostrém kontrastu k rozšířené teorii (zejména v německém hospodářství) je Piketty relativně shovívavý k řešení státního dluhu vyšší inflací. Upozorňuje na známou skutečnost, že dluhy jsou v současné Evropě nominální, nikoli reálné aktivum. Vyšší inflace podle Pikettyho ,zdaní “ především ty, kdo zbytečně drží volné peníze místo toho, aby je investovali. Jedná se tedy podle něj o spravedlivou daň, která zbaví peněz ty, kdo „stejně nevědí, jak s nimi naložit“, a zároveň ušetří dlužníky a podnikatele. Je otázkou, jak by Piketty vysvětloval německým ekonomům s jejich meziválečnou hyperinflační zkušeností svůj postřeh, že , inflace je lepši než škrty“. I v tomto bodu lze tedy jednoznačně identifikovat Pikettyho fascinaci socialistickou hospodářskou politikou - obdobné argumenty jako dnes Piketty používal ve 20. letech 20. století sovětský ekonom a politik E. A. Preobraženskij.

Uvedené výhody inflace jsou podle Pikettyho důvodem, proč centrální banky Spojených států, Velké Británie či Japonska usilují o zvýšení inflačního cíle. Toto tvrzení je ovšem opět značně nepřesné - například Fed se explicitně vymezuje vůči zvyšování inflačního cíle. Jednou z nevýhod inflačního oddlužování pak dle Pikettyho je, že by tento proces trval několik desetiletí.

Řadu nepřesností pozorný čtenář nalezne také v kapitole věnované kyperské krizi (str. 627 a další.) Piketty zde například uvádí: „Všichni vědí, že kyperský střadatel s 10000 eur i ruský oligarcha s 10 miliony eur budou zdaněni téměr stejně." Jedná se o velmi pozoruhodný výrok. Podle daňových sazeb, které ve stejné kapitole udává, by totiž „,chudý kyperský střadatel“" odvedl v rámci jednorázové krizové daně 675 eur, zatímco „,ruský oligarcha“ 989685 eur. Částky, které lze za „téměř stejné“ považovat jen se značnými obtížemi.

Z hlediska současné migrační krize je pak pozoruhodný Pikettyho pohled na imigraci, kterou považuje za žádoucí mírovou formu redistribuce a regulace světové kapitálové nerovnosti (str. 609).

Thomas Picketty bezesporu připomíná novodobého Marxe nejen odkazem na název základního opusu, ale především souborem ideologických hodnot. Zájem o historický vývoj kapitalismu, dynamiku akumulace a sociální nerovnost je společný i marxistickým ekonomům.

Pikettyho Kapitál v 21. století není přes veškerou snahu odbornou ekonomickou knihou. Autor ostatně v závěru knihy sám přiznává, že nesouhlasí s termínem „ekonomická věda“. O to nebezpečnější však pro budoucnost západních ekonomik je. 
Ekonomická terminologie a úctyhodný rozsah propůjčují publikaci zdání vědeckosti (a tedy něčeho, oč se mohou oficiálně opírat tvůrci hospodářských politik i tvůrci veřejného mínění). Relativní čtivost, srozumitelnost a nabízení rychlých a snadných řešení pak usnadňuje šíření těchto nebezpečných myšlenek mezi nejširší okruh (neekonomických) čtenárůu.

Demokracie má podle Pikettyho ,převzít kontrolu nad kapitálem” (str. 647), aniž by autor dále vysvětlil, jak by taková antikapitalistická demokracie mohla demokracií zůstat. Na jiném místě pak v marxistickém duchu píše, že „kapitálové výnosy v sobě neoddělitelně kombinuji prvky skutečné podnikatelské práce, obyčejného štěstí a zlodějny” (str. 498) a mluví o „bezskrupulózních finančních poradcích“ (str. 333). Není proto překvapivé, že spolu s Ricardem považuje Piketty za pravděpodobně nejvýznamnějšího ekonoma 19. století Karla Marxe (str. 23).

Doporučení v podobě silného zdanění kapitálu a důchodu jsou možná mírumilovnější způsoby než proletářská revoluce, jeho důsledky jsou však podobné: oslabení svobody a motivace podnikat a pracovat. Pickettyho knihu proto lze doporučit k četbě - jako výstražný př́klad. 